\title{
CORRUPTION AS A NEGATIVE SOCIAL PHENOMENON
}

\begin{abstract}
This paper analyzes the problem of corruption as a phenomenon, a negative and illegal social phenomenon, which is contrary to the rules of normal functioning of the society. It implies to very serious consequences which can produce a real threat and the possibility of adopting corruption as a negative model of life and activity, that is, the functioning of the society, personified in several corrupt individuals and groups. The state continuously applies anti-corruption mechanisms. However, a phenomenon that is difficult to eradicate is the multitude of individual cases of offering, giving, or soliciting bribes in certain everyday life circumstances. We are worried about the researches indicating that a large number of the state institutions are exposed to corruption, including the officials employed in these institutions using corrupt actions during the performance of their regular work. The basic question that arises is whether a certain number of citizens who do not accept corruption over time become "antisocial" in relation to the individuals representing a part of the society which accepts it as an adopted model, or a way of living and normal functioning being contrary to law and the commitment of the state in the fight against corruption. The aim of the research is how to prevent the adoption of the corruption model as a "value", by reporting it to the competent authorities in Republic of Serbia, including the fight against corruption through the socalled "Romanian model", proved to be very effective in fighting corruption.
\end{abstract}

Keywords: corruption, society, prevention, values, reporting

\footnotetext{
${ }^{*}$ LLB, The Faculty of Law for Commerce and Judiciary in Novi Sad, The University of Business Academy in Novi Sad, Serbia, e-mail: kovacevicsasa44@yahoo.com
} 


\section{Introduction to the phenomenon of corruption}

The reason for researching the phenomenon of corruption is reflected primarily in the need to scientifically investigate this phenomenon as an obvious psychological problem of many individuals who consider and accept corruption as a reality, a "value" and the only correct way of societal function, which is a very significant problem for our state, and moral and material values of society. The issue of the phenomenon of corruption, or the potential danger of adopting corruption as a "value", in every society presupposes a "red tape" for a state that perceives corruption as a danger to society. The state has and uses very serious resources in the fight against corruption, which is ultimately commendable, but a certain number of citizens believe and persist in their intention to adopt corruption as a "value" in society or impose it as a normal phenomenon, which, according to their understanding, would become a part of the daily functioning of each individual in the social environment. Such a primarily destructive way and approach is contrary to legal and moral norms for a very large number of citizens, who do not accept corruption and seriously advocate for its elimination with the help of the state, by reporting corruption to the competent state authorities with absolutely correct expectations that the state will act promptly and will sanction all forms of corruption in society. This research aims to define the concept and problems of corruption, pointing to all available manifestations and the "red tape", in the adoption of corruption as a "value" in society, whilst directing the competent state institutions to eliminate corruption as one of the state priorities through the timely intervention of the state and authorized state bodies to prevent all types of corrupt activities.

\section{Phenomena of corruption regarding historical aspects}

In the manifestations of corruption, it is irrelevant whether it is a matter of giving or receiving a bribe. Comprehensively, corrupt individuals can be from various spheres of society, legislative, executive and judicial authorities, politics, local self-government, health, police, and similar, all the way to the lowest instances with which ordinary citizens have daily communication. Corruption is a very complex phenomenon in society, with many causes and consequences that it produces, it represents a political, economic, and cultural problem, as well as, an individual and moral problem. It is very widespread and present in many countries of the world and that is why it is very difficult to eradicate. Criminologists believe that corruption should be reduced to a 
tolerable measure, in other words, a "reasonable level", in society (Bjelajac, 2013, p. 345).

In this regard, it is necessary to point out that the phenomenon of corruption is one of the biggest problems faced by the most developed countries of European Union, according to surveys, one in five surveyed citizens of the European Union believes that corruption is one of the biggest problems to EU member states, because economic costs based on corruption exceed 120 billion euros annually (Vuković, 2017, p. 104). To better understand the origin of corruption as a phenomenon, it is necessary to look at corruption in the time of the Roman Empire, i.e., ancient Rome, where political corruption was especially pronounced, due to a large number of abuses by leading people in important and powerful positions in Rome. Bribery was one of the basic characteristics of the bureaucracy and public servants, as holders of important state functions. On the one hand, there is a noticeable will to condemn such manifestations in society, and on the other hand, a desire to acquire wealth, privileges, titles, and advancement in the service is prevalent, which the people accepted over time, and adopted it as a model of life at that time. Over time, the Romans defined the saying "that everything can be bought in Rome", which resulted in the collapse of the Roman Empire (Deretić, 2017, p. 769).

When it comes to our area, historically, the subjected past has a very large impact on the acceptance of corruption, or corrupt practices as a way of life of the people in this area. How much we have personally influenced the positive attitude towards society, and the community, and how much we have managed to change the awareness of corruption, and how much we have historically accepted it, is one of the basic issues of today's modern society. In general, corruption in Serbia is a historical problem, which is based on the functioning of the state based on the discretionary powers of the rulers, which partly characterizes modern-day Serbia. Discretionary powers enable the creation of injustice and abuse by individuals or groups. Precisely, the historical presence of subservience in this area defines today's patterns of behavior of individuals with the presence of corrupt elements. The resistance of political elites is largely deserved, for all forms of corrupt behavior in today's modern Serbia, and its society. Serbia has failed to change its way of life, that is, to break the link with inherited behavior in the area of corruption, despite the very pronounced presence of a large number of legal norms and regulations meant to fight against corruption. Only the personal identity of each individual or group has and has had the opportunity to change the awareness of corruption (Todorović, 2014, pp. 91-102). 
Corruption itself is a phenomenon in society, which is mainly a product of power, for the reason that a group or individual power is largely achieved through interest, regardless of the opposition of others. Politics, power, and influence, create the basic preconditions for corruption and material gain. Power is mainly defined through wealth and a certain social position, which is characterized by economic, political, and spiritual power, while this power can manifest itself through institutions, and this type of power is called institutionalized power. It is carried out through a certain position, and/or function. Thus, corruption in a general sense is an abuse of public office for private gain. These types of abuses deviate from legal regulations and moral norms resulting in legal and moral penalties.

In general, corruption is a pronounced socially unacceptable and negative phenomenon, which arises and is manifested in society in all its forms, depending on political, economic, social, and other circumstances, which results in immoral, antisocial, and illegal manifestations which cause enormous consequences for the state and society as a whole (Đukić, 2019. p. 157). When it comes to political corruption as a form or type of corruption in Serbia, the basic problem stems from individual cases of weakness of the political system, as the organization of society that is abused by individuals. Individual cases of lack of political will to fight corruption, non-transparency of functioning and financing of political parties in some cases, the constitution of informal centers of power, and connection of individuals from the ranks of politicians with organized crime are mostly basic characteristics of political corruption. When it comes to economic forms of corruption, the causes are mainly the transitions of developed and underdeveloped countries, poverty and unemployment as one of the basic characteristics of modern society and activity, which greatly affect the development of corruption. They are characterized by dubious privatizations and the monopoly of large transnational companies, with an emphasis on the non-existence of equal market conditions, and the existence of market monopolies. The legal causes are dominated by weaknesses in the functioning of the legal system, and lack of accountability, with an emphasis on a very pronounced conflict of interest. The connections of corrupt individuals from state bodies and links with organized criminal groups produce as a result the institutional causes of corruption in Serbia. All these causes affect the distrust of citizens towards institutions, primarily in the legal system and state bodies (Božić \& Nikač, 2018, p. 805).

Analyzing comprehensively corruption and individual forms of corruption in the Republic of Serbia, concerning some of the historical aspects of corruption, it can be concluded that corruption in Serbia as in other countries 
is present as an illegal phenomenon in society, to the extent that cannot be qualified as "Reasonable level", regardless of the state's determination to deal with all possible forms of corruption. Individual cases from different structures of society represent the dominant carriers of corruption, and the main stronghold of corruption, starting from individual government structures to the lowest structures where there is a possibility of corruption in individual cases, which may result in possible acceptance of corruption as a "value", in other words, way of functioning in a society with unforeseeable consequences, which historically point to the period of ancient Rome, where through the adopted model of corrupt business one could "conditionally buy everything".

\section{The role of state authorities with an emphasis on the Public Prosecutor's Office in corruption prevention}

One of the primary priorities of state bodies is corruption prevention. However, there are various limitations in these efforts of state bodies, both systemic and moral, which largely depend on the most significant institutions that have all the levers at their disposal in the fight against corruption. When it comes to the anti-corruption strategy in the Republic of Serbia, and the strategic approach in the fight against corruption, it dates back to 2005, with the adoption of the National Strategy for the Fight against Corruption. An important role is performed by the Service for Fight against Organized Crime, which operates within the Ministry of Internal Affairs of the Republic of Serbia, as well as the Anti-Corruption Agency, which has been operating as an independent state body since 2009. A special anti-corruption department has been established within the Public Prosecutor's Office, appellate and higher public prosecutor's offices (Đekić, Čukanović \& Filipović, 2018, p. 105).

It is very important to clearly and precisely explain the role of the Public Prosecutors Office, how and in what way it functions, and what competencies it has. It has very broad powers. All state bodies, including the police, which are responsible for detecting criminal acts, are obliged to act upon the request of the prosecutor's office. Based on the clearly defined role of the prosecution, it can be concluded that the prosecutor's office directly bears most of the responsibility in bringing up indictment charges for corruption offenses. Criminal acts involving corruption can be defined in a narrower sense, as acts in which actions are sanctioned as exclusively corrupt (receiving bribes, giving bribes, giving and receiving bribes in connection with voting, receiving bribes in performing commercial activities and trading in influence), and 
criminal acts involving corruption in a broader sense, in which the act of execution appears as a consequence of corruption, but corruption itself "cannot be proven", which includes a large number of crimes against official duty and commercial crimes (Center for Judicial Research, CPI, 2017).

A significant number of citizens of Serbia, equate the prosecution, the court, and the police, at the same time attributing to everyone the responsibility for a possibly passive attitude towards sanctioning corruption. It is important to point out that the greatest responsibility lies in the prosecutor's office, and the superficial and unprofessional approach of individuals in this state body is inadmissible because it would largely contribute to the adoption of the model of corruption as a "value". Also, superficially and imprecisely formulated indictments and unfounded determination of several months of detention, and after that payment of multimillion damages to injured parties without any responsibility to prosecutors, which, in turn, cause multimillion damages to the budget of the Republic of Serbia. When it comes to detention as one of the most stringent measures to ensure the presence of the accused to conduct the criminal proceedings without hindrance, it is first of all necessary to very clearly and precisely lay out the rules and reasons for determining detention One of the basic conditions for determining detention is "reasonable doubt", with the fulfillment of one of the four alternatively set optional reasons, which is clearly and decisively defined through the reasons for ordering detention in the criminal procedure legislation of the Republic of Serbia about the practice of domestic courts and the European Court of Human Rights "(Matijašević \& Joksić, 2019, p. 108). The law stipulates that if the damage was caused by the prosecutor's office intentionally or through gross negligence, the Republic of Serbia may request compensation from the public prosecutor, or the deputy public prosecutor.

Of course, the responsibility of other state bodies with an emphasis on the Anti-Corruption Agency, which mainly serves to issue warnings in the area of conflict of interest, as well as the "directing" of the State Audit Institution through warnings about misuse of budget funds in multimillion amounts, without taking action against the prosecution, transferring legal obligation onto someone else to report. "Who should report, when and to whom to report a corruption crime" becomes one of the biggest dilemmas, when someone misuses huge budget funds with intent and illegal corrupt actions, except for the records, and the findings of the State Audit Institution, no further measures and procedures are taken. Which ultimately greatly encourages irresponsible individuals in society to commit corruption, and take part in corrupt practices. 


\section{Refusal of corruption as a societal "value"}

The problem of corruption, as the basic question that is hypothetically raised through the adoption of corruption as a societal "value" by irresponsible individuals, is easiest to compare with the experiences of some countries in the world, where corruption is already adopted as a "value". An example of one of the most corrupt countries in the world - India, with a very small percentage of citizens who are not partaking in some of the very large numbers of corruption activities, where citizens who do not support corruption are considered "antisocial citizens". The example of India points to the very negative consequences of corruption, which arise as a result of the untimely reaction of the state, which has produced the adoption of corruption as a societal "value" and the emergence of "corruptly anti-social citizens", who are responsible citizens trying to resist corruption, but the accepted system of "corruption values" prevents them. When it comes to our state, it is an unwritten rule that all corrupt service directed towards citizens have their price. From the smallest services of issuing the most ordinary certificates and documents, speeding tickets, where the perpetrator and the police officer profit and the state loses, operations in health care institutions, corrupt services at all academic levels, health, education, local self-government, all the way to mysterious corruption inside the justice that is difficult to prove and so on. The basic question is, who the facilitators of corruption are and what types of corruption do citizens encounter through everyday life and work in the community. According to some determinants, the most characteristic and most common is the so-called "street corruption", or spontaneous bribery, as a phenomenon or adopted form of corruption, which characterizes bribery of public officials and responsible persons in order to avoid certain legal obligations and to achieve certain benefits and privileges, to which they are otherwise obliged by law. This group includes corrupt inspectors of various inspections, officials at various levels of government, customs officers, police officers, and similar officials. Political corruption, as a type of corruption, has one of the most devastating effects on the economy and society in general, the reasons are clear and evident, reflected in the adoption of faulty laws full of legal gaps, it is also characterized by voter fraud in the election campaign, sponsoring political parties to avoid certain legal obligations, obtaining certain perks, etc. As a form of corruption, the so-called "contracting corruption" is evident, which means corruption in public administration as an adopted model based on concluding harmful contracts for services and joint-ventures with an inescapable corrupt commission, most common in the public procurement process. Nepotist 
corruption is a form of corruption that is also widespread, it is characterized by employment, and filling of appropriate state official positions in government with friends, relatives, and close people. Judicial or prosecutorial corruption is also common, which is characterized by abuse of the position of judicial functions. Transactional, extortion, investment, and all other forms of corruption are also in use, which can be subsumed under the term of general corruption, which partly includes construction, health, education, sports, and similar commercial activity (Ignjatić \& Čavlin, 2017, p. 38).

Overall, when it comes to the social community as a whole, citizens have significantly fewer points of contact between them. They have the opportunity to choose the appropriate option and modality of wishes and needs, not taking into account the interests and needs of other citizens, guided by purely selfish interests, with an emphasis on strength and power in the social ladder. As result supremacy is a key determinant of social status, in other words, acquiring a superior position that dominates and is above individuals who are in a subordinate position. Besides, politics works most effectively in creating unlimited power of individuals or groups, which results in the realization of the interests of powerful people in power, and public officials (Joković, 2017, p. 458).

Based on all of the above-mentioned, it is not disputable to conclude that there is a certain expansion of corruption, despite a large percentage of citizens being against it. If the state does not react efficiently and expeditiously, extensive damage can be done to the social thread, which is very difficult to compensate later, especially if corruption is adopted as a societal "value". It is very important to emphasize that corruption is not exclusively illegal behavior, corruption generally degrades all moral norms, emphasizes and promotes corruption, nepotism, dishonesty, depravity, or the worst possible deviations in behavior (Bjelajac, 2013, p. 344). On the flip side, a very large part of the social body refuses to accept corruption as a value and an adopted model of the way of life and functioning of the system in the Republic of Serbia. It is clear that in the majority of society, corruption has no foundation, however, without the clear and unequivocal support of the state, and state bodies, there will be no progress in the prevention of corruption.

\section{Reporting corruption through the "Romanian model"}

To report or not to report corruption in the Republic of Serbia is one of the most sensitive issues, and a dilemma of every individual in society, taking into account, on the one hand, the moral, honest, conscientious and responsible attitude of every individual belonging to the community. And on the 
other hand, the consequences that could greatly negatively affect and that the individual reporting corruption must be prepared for. Every citizen is aware of the corruption, they recognize corruption as illegal behavior, contrary to the moral norms of every human being, as abuse of power to achieve personal goals and illegal enrichment. Furthermore, citizens clearly recognize that corruption is not a modern occurrence, in fact, it is a historical recurrence, and that corruption cannot be completely eradicated, on top of that, corruption is very adaptable in almost all systems of the state organization. When it comes to forms of corruption, which all citizens can recognize and report, Serbia is mainly characterized by emerging forms of corruption recognized as, classic, political, systemic, VIP corruption, mobbing, discrimination, abuse of political power, abuse of public service, influence trading and ethnic-tribal-kinship ties, which was also covered by research from 2013 (Dugalić, 2014, p. 8).

One of the key questions for the citizens of Serbia is whether there is a moral obligation to report corruption, is it necessary to comply with legal norms in the field of corruption, if the present data and all analyzes unequivocally indicate that almost no one in power has been prosecuted, and there is a very small number of processed cases, in accordance with the law on criminal offenses of corruption (Vujović, 2014, p. 109).

In order to explain as precisely as possible how and in what way it is possible to solve, and act against corruption, as one of the proposals, and possible modalities that can be used in Serbia, we will cite the example of Romania, a country with a very high level of corruption in the previous period, that is also an EU member. Romania is placed very high when it comes to corruption, from the smallest to the biggest corruption scandals among EU member states. Laura Kodruca Kovesi has been appointed head of the Romanian Anti-Corruption Directorate since 2013, as chief prosecutor. During the five years she spent in the office, she indicted 68 senior officials and brought them to court, including 14 current or former government ministers and 53 lawmakers from both houses of the Romanian parliament. When she was replaced in 2018, 37 of those politicians had already been convicted, and other lawsuits were ongoing (Torp, 2019).

She was replaced by the political elite, more precisely, she was replaced by the Social Democrats, who considered the chief prosecutor the arch-nemesis, and, interestingly, the civil servants who were prosecuted belonged to different political parties. So, there was no selection by party affiliation. (ACD) The Anti-Corruption Directorate was established in 2003, it has launched about 43,000 investigations and indicted over 12,300 people for further court proceedings, in the area of political corruption, and filed charges against 23 former and current ministers in the Government, including former Prime Minister 
Adrian Nastase, who was prosecuted and ended up with a prison sentence. Investigations have been conducted against district council presidents, mayors, and members of parliament, mostly for political corruption. Prosecutor Laura Kodruca Kovesi insisted on public arrests, sending a message to citizens to report corruption, similarly arresting the mayor of Constanta Mazara in a spectacular action in 2014, who was sentenced to six and a half years in prison for abuse of office, in a similar way Labor Minister Lia Olguta Vasilescu was also arrested. In the end, political corruption managed to influence the president, to replace the prosecutor in 2018, due to the alleged abuse of position and excessive use of resources for wiretapping by the secret service. She was accused of pressuring witnesses and fraud. The prosecutor had the huge support of the citizens of Romania, she rejected all accusations as false and politically fabricated, by corrupt individuals from political structures. A vast number of citizens expressed concern, because (ACD) was the only pillar of Romania's defense against political corruption, citizens were greatly encouraged by the prosecutor's attitude and began to report corruption and cooperate with (ACD) in prosecuting corrupt individuals. In the end, the Romanian prosecutor was nominated and suggested as the EU chief prosecutor. It is interesting to note that the prosecutor connected the secret service with the judicial system, she was accused of secretly signing a protocol on cooperation with the secret service, she was criticized for that, as well as for the fact that she allegedly "abused her power" when she initiated investigations, which resulted in the dismissal of the indictments for the mentioned crimes, by the end of 2018 (Burtea, 2018).

Serbia has adopted a different approach and formed the AntiCorruption Agency and the Anti-Corruption Council without the right to indict. Through the above example, it can be concluded that one of the proposed modalities is the aforementioned way of functioning of the Prosecutors Office through absolute cooperation with the Anti-Corruption Agency, and the unification of activities through the formation of a specialized body within the Anti-Corruption Agency as an independent body, independently managed and detached, and specialized part of the Prosecutor's Office for Corruption, which would have at its disposal a permanently employed part of the police force in its composition. In that way, independence in investigation activities would be ensured, through a specialized part of the professional staff of legal and economic profession, which would be led by a specialized team from the prosecutor's office with available executive part of police structures, which would be tasked with a specific investigation. The entire team would function based on a special law and would be solely accountable for its work to the Serbian Parliament, through the obligation to submit reports in closed 
sessions of the Specialized Assembly Board, which could only influence with the two-thirds majority the replacement of team members and other questions, of course with an absolute legal explanation of their decisions.

\section{Conclusion}

Analyzing the phenomenon of corruption in Serbia, and the manifestations of corruption, including historical aspects, it can be unequivocally concluded that corruption has been present in Serbia since ancient times and does not represent a newly adopted manifestation. The role of state bodies, primarily the prosecutor's office, is of key importance in combating corruption. In addition, the decisive non-acceptance of corruption by a majority of citizens, with an emphasis on one of the most important issues, reporting corruption, is the basis, or the basic precondition for removing the red tape in the fight against corruption. If we take into account that corruption is a problem that affects both developed and underdeveloped societies and is one of the burning problems in the world, the justified question of whether the collapsing the fundamental values of each society can be expected. All reforms and democratic processes can be annulled by corruption. It is not enough to adopt adequate international conventions and regulations, which will serve Serbia in building institutional mechanisms, and specialized anti-corruption bodies. It is necessary to also apply them, the instructions of all relevant international institutions must be respected, primarily the recommendations of the GRECO organization, which since 2017 insists on strengthening the independence of the prosecutor's office without political influence and the independence of the judiciary with an emphasis on apt staff.

Reporting corruption to the authorities prevents the adoption of the corruption model as a "value". Based on the experiences of neighboring countries, it is necessary to apply a model similar to the Romanian model as a way of managing prosecution, which gave very good results in the fight against corruption, in addition, some other European countries have similar models. An independent Prosecutor's Office with a professionally trained special police unit, as a permanent fixture, is the only and real solution to the problem of corruption in Serbia. It is quite realistic and the example of Romania indicates that a significant number of Serbian citizens would thus identify and report corruption to the Prosecutor's Office. In addition to gaining trust in institutions, this method would also build a comprehensive system of values and responsibilities in Serbia. Only and exclusively state bodies can and must, by personal example, influence citizens to report corruption. By involving 
the state in the comprehensive fight against corruption, citizens' trust in the state and state bodies will return, citizens will report even the smallest forms of corruption, with an emphasis on prevention and then the application of repressive measures against individuals and groups in accordance with the law.

\section{Kovačević Saša}

Diplomirani pravnik, Pravni fakultet za privredu i pravosuđe u Novom Sadu, Univerzitet Privredna akademija u Novom Sadu, Srbija

\section{KORUPCIJA KAO NEGATIVNA DRUŠTVENA POJAVA}

REZIME: U radu se analizira problem korupcije kao fenomena, odnosno negativne i nezakonite društvene pojave, koja je u suprotnosti sa pravilima normalnog funkcionisanja društva, sa veoma ozbiljnim posledicama koje proizvodi i koje realno ukazuju na potencijalnu pretnju i mogućnost usvajanja korupcije kao negativnog modela načina života i rada, odnosno funkcionisanja društva, od strane jednog dela korumpiranih pojedinaca i grupa. Država kontinuirano primenjuje mehanizme suprotstavljanja korupciji. Međutim, pojava koju je teško iskoreniti jeste mnoštvo pojedinačnih slučajeva nuđenja, davanja, ili traženja mita u nekim svakodnevnim životnim okolnostima. Istraživanja zabrinjavaju i ukazuju, da je ne tako mali broj državnih institucija izložen korupciji, odnosno službenici koji su zaposleni u tim institucijama, podrazumevaju koruptivne radnje u toku vršenja svog redovnog posla. Osnovno pitanje koje se postavlja je, da li deo građana koji ne prihvata korupciju vremenom postaje "asocijalan" u odnosu na pojedince, odnosno deo društva, koji istu prihvata kao usvojen model, odnosno kao način života i normalnog funkcionisanja, što je u suprotnosti sa zakonom i zalaganjem države u borbi protiv korupcije. Cilj istraživanja je, kako i na koji način sprečiti usvajanje modela korupcije kao "vrednosti", prijavljivanjem iste nadležnim organima u Republici Srbiji, uključujući i način borbe protiv korupcije kroz takozvani "Rumunski model", koji se pokazao kao veoma efikasan u borbi protiv korupcije.

Ključne reči: korupcija, društvo, sprečavanje, vrednosti, prijavljivanje 


\section{References}

1. Bjelajac, Ž. (2013). Organizovani kriminalitet [Organised Crime]. Pravni fakultet za privredu i pravosuđe, Novi Sad

2. Božić, V. \& Nikač Ž. (2018). Korupcija i njeno suzbijanje u tranzicionim društvima: primer Hrvatske i Srbije [Corruption and its suppression in transitional societies - the example of Croatia and Serbia]. Sociološki pregled, 52 (3), pp. 801-831

3. Burtea, J. (2018). Zavadi pa vladaj: Kako je Rumunija izgubila rat protiv korupcije [Divide and Conquer: How Romania lost the war against corruption], Downloaded 2020, February 20 from www.danas.rs > Svet

4. Centar za pravosudna istraživanja, (2017). Uloga tužilaštva u borbi protiv korupcije i organizovanog kriminala u Republici Srbiji [The role of the prosecution in the fight against corruption and organized crime in the Republic of Serbia]. Beograd, Downloaded 2020, February 22 from www.cepris.org > uploads > 2017/12 >finalna verzija

5. Deretić, N., Lj. (2017). Suptilna i neodoljiva primamljivost korupcije u političkim krugovima Rima [The Subtle and Irresistible Allure of Corruption in the Political Circles of Rome]. Zbornik radova Pravnog fakulteta, Novi Sad. 51 (3-1), pp. 767-790

6. Dugalić, V. (2014). Korupcija je hidra sa bezbroj glava [Corruption is a hydra with countless heads]. Bankarstvo, 43 (6), pp. 6-15

7. Đukić, S. (2019). Analiza specifičnosti izvora korupcije i bezbednost društva [Analysis of the specifics of the sources of corruption and security of society]. Vojno delo, 71 (4), pp. 156-171

8. Đekić, M., Čukanović-Karavidić, M. \& Filipović, P. (2018). Korupcija kao oblik finansijske prevare i njena zastupljenost u Srbiji [Corruption as a form of financial fraud and its prevalence in Serbia], Revizor, 21 (81), pp. 101-113

9. Ignjatić, S. \& Čavlin, M. (2017). Analiza uzroka i posledica korupcije u društvu [Analysis of the causes and consequences of corruption in society]. Oditor, 3 (3), pp. 35-50

10. Joković, M. (2017). Interesi i korupcija [Interest and Corruption], Sociološki pregled, 51 (3). pp. 457-476

11. Matijašević-Obradović, J. \& Joksić, I. (2019). Razlozi za određivanje pritvora u krivičnoprocesnom zakonodavstvu Republike Srbije uz osvrt na praksu domaćih sudova i Evropskog suda za ljudska prava [Reasons for ordering detention in the criminal procedure legislation of the Republic 
of Serbia with reference to the jurisprudence of domestic courts and the European Court of Human Rights]. Vojno delo, 71 (2), pp. 108-119

12. Todorović, Z. (2014). Korupcija u Srbiji istorijsko-kulturološki aspekti [Corruption in Serbia, historical and cultural aspects]. Bezbednost, Beograd, 56 (1), pp. 88-103

13. Torp, N. (2019). Rumunska borkinja protiv korupcije kandidatkinja za prvog evropskog tužioca [Romanian anti-corruption fighter is a candidate for the first European prosecutor], Downloaded 2020, February 22 from www.bbc.com > serbian > lat > svet-47618746-19.03.2019

14. Vujović, S. \& Vujović, T. (2014). Mito i korupcija na mapi sveta i Srbije [Bribery and corruption on the map of the world and Serbia]. Ekonomski pogledi, 16 (1), pp. 145-161

15. Vuković, S. (2017). Merenje efekata prevencije korupcije [Measurment of Effects of Corruption Prevention], Bezbednost, Beograd, 59 (3), pp. $101-118$ 